\title{
PEMANFAATAN TEPUNG KEONG MAS (Pomacea canaliculata) SEBAGAI SUBSTITUSI TEPUNG IKAN PADA PAKAN UDANG VANNAMEI (Litopenaeus vannamei) TERHADAP NILAI KECERNAAN SERAT KASAR DAN BAHAN EKSTRAK TANPA NITROGEN (BETN)
}

\section{Utilization of Golden Snail (Pomacea Canaliculata) Flour as a Substitution Fish Feed Vannamei Shrimp (LitopenaeusVannamei) Feed For Digestibility Value of CrudeFiber And Nitrogen Free Extract (NFE)}

\author{
Agustono $^{1 *}$, M. Anam Al Arif ${ }^{2}$ dan Farah Sitta Dewi ${ }^{3}$ \\ ${ }^{1}$ Program Studi Budidaya Perairan, Fakultas Perikanan dan Kelautan, Universitas Airlangga, Surabaya \\ ${ }^{2}$ Departemen Manajemen Kesehatan Ikan dan Budidaya Perairan, Fakultas Perikanan dan Kelautan, Universitas \\ Airlangga, Surabaya \\ ${ }^{3}$ Fakultas Kedokteran Hewan, Universitas Airlangga, Surabaya \\ *guston_bp@yahoo.com
}

\begin{abstract}
Abstrak
Udang vannamei (Litopenaeus vannamei) satu dari beberapa komoditas bernilai ekonomis tinggi yang produksi budidayanya selalu meningkat. Pakan memegang peranan penting dalam proses budidaya. Pemanfaatan tepung keong mas yang dapat menggantikan fungsi tepung ikan. Kualitas pakan ditunjukkan melalui nilai kecernaan nutrisi dari pakan. Karbohidrat merupakan salah satu komposisi nutrisi yang diperlukan dalam pembuatan pakan. Karbohidrat dalam sistematika susunan zat-zat makanan dipisahkan menjadi serat kasar dan Bahan Ekstrak Tanpa Nitrogen (BETN). Tujuan penelitian untuk mengetahui pengaruh substitusi tepung ikan dengan menggunakan tepung keong mas terhadap nilai kecernaan serat kasar dan Bahan Ekstrak Tanpa Nitrogen (BETN) udang vannamei (Litopenaeus vannamei). Penelitian ini menggunakan 4 perlakuan yaitu pakan P0 (Tepung ikan $40 \%+$ Tepung keong mas $0 \%$ ), pakan P1 (Tepung ikan 30\%+Tepung keong mas $10 \%$ ), pakan P2 (Tepung ikan $20 \%+$ Tepung keong mas $20 \%$ ) dan pakan P3 (Tepung ikan $10 \%+$ Tepung keong mas30\%) dengan ulangan sebanyak 5 kali. Rancangan penelitian yang digunakan dalam penelitian ini adalah Rancangan Acak Lengkap (RAL). Variabel yang diamati adalah kecernaan serat kasar, dan kecernaan bahan ekstrak tanpa nitrogen (BETN).Berdasarkan hasil penelitian dapat terlihat bahwa pemanfaatan tepung keong mas (Pomacea canaliculata) sebagai substitusi tepung ikan pada pakan udang vannamei (Litopenaeus vannamei) tidak terdapat pengaruh yang nyata $(\mathrm{P}>0,05)$ terhadap nilai kecernaan serat kasar dan Bahan Ekstrak Tanpa Nitrogen (BETN).
\end{abstract}

Kata kunci: tepung ikan, tepung keong mas, udang vannamei

\begin{abstract}
Vannamei shrimp (Litopenaeus vannamei) is one of the high value commodity has always increasing cultivation production. Feed have an important role in the process ofcultivation. Utilization of snail flour can replace fish meal as a producer of animal protein in feed is expected to reduce feed costs. Feed qualityis indicated by the value of the nutrient digestibility of feed. Carbo-hydrates are one nutrient composition required in the manufacture of feed. Carbohydrates in the systematic arrangement of food substances is separated into crude fiber and Nitrogen Free Extract (NFE). This research aims to determine the effect of substitution of fish meal by using snail flour for digestibility value of crude fiber and Nitrogen Free Extract (NFE) on vannamei shrimp (Litopenaeus vannamei).

This research uses four treatments that is (Fish meal 40\% + Flour snail $0 \%$ ), P1(Fish meal30\% + Flour snail 10\%), P2(Fish meal20\% +Flour snail 20\%) andP3(Fish meal10\% +Flour snail 30\%) with 5 replications. Digestibility value measurement method used is indirect method by using indicators. Observed variables are digestibility ofcrude fiber and digestibility of Nitrogen Free Extract
\end{abstract}


(NFE).Based onthe results ofthe research can be seen in the utilization of golden snail (Pomacea canaliculata) flour as a substitute fish meal on vannamei shrimp (Litopenaeus vannamei) feed there are no significant effect $(\mathrm{P}>0.05)$ on the digestibility value of crude fiber and Nitrogen Free Extract ( NFE).

Keywords: fish meal, flour snail, vannamei shrimp

\section{Pendahuluan}

Udang vannamei (Litopenaeus vannamei) satu dari banyak komoditas bernilai ekonomis tinggi yang produksi budidayanya selalu meningkat. Pakan memegang peranan penting dalam proses budidaya. Tepung ikan merupakan salah satu sumber protein terbaik untuk pakan, tetapi harganya relatif mahal. Salah satu alternatif untuk memecahkan masalah pakan tersebut adalah dengan pemanfaatan tepung keong mas (Pomacea canaliculata) sebagai substitusi tepung ikan dalam ransum, untuk mengetahui apakah tepung keong mas dapat menggantikan fungsi tepung ikan sebagai penghasil protein hewani (Tarigan, 2008).Kualitas pakan ditunjukkan melalui nilai kecernaan nutrisi dari pakan. Karbohidrat merupakan salah satu komposisi nutrisi yang diperlukan dalam pembuatan pakan. Karbohidrat dalam sistematika susunan zat-zat makanan dipisahkan menjadi serat kasar dan Bahan Ekstrak Tanpa Nitrogen (BETN).

Serat kasar berisi selulosa, hemiselulosa dan lignin (Tillman dkk., 1983). Tingginya kandungan serat kasar pada pakan akan mempercepat laju perjalanan makanan di dalam saluran pencernaan dan berdampak pada menurunnya kesempatan saluran cerna menyerap zatzat makanan lainnya yang terdapat di dalam pakan (Bakara dkk., 2012). BETN terdiri dari gula, pati, pentosan, dan bahan-bahan penyusunlain yang memiliki nilai kecernaan yang tinggi. (Budiman dkk., 2006). Berdasarkan hal yang telah diuraikan inilah yang kemudian mela-

tarbelakangi penelitian pemanfaatan tepung keong mas (Pomacea canaliculata) sebagai substitusi tepung ikan pada pakan udang vannamei (Litopenaeus vannamei) terhadap nilai kecernaan serat kasar dan dan Bahan Ekstrak Tanpa Nitrogen (BETN) perlu dilakukan.

\section{Metodologi}

\section{Tempat dan Waktu Penelitian}

Penelitian ini dilaksanakan pada tanggal 7-25 April 2014 di laboratorium Fakultas Perikanan dan Kelautan, Universitas Airlangga Surabaya. Analisis proksimat dilakukan di Unit Layanan Pemeriksaan Laboratoris, Konsultasi dan Pelatihan Fakultas Kedokteran Hewan, Universitas Airlangga Surabaya. Analisis dengan menggunakan Cromium oxide $\left(\mathrm{Cr}_{2} \mathrm{O}_{3}\right)$ dilakukan di Laboratorium Nutrisi dan Teknologi Pakan, Balai Penelitian dan Pengembangan Budidaya Air Tawar Sempur Bogor.

\section{Metode Penelitian}

Metode penelitian yang digunakan dalam penelitian ini adalah metode eksperimental atau percobaan.Penelitian ini menggunakan 4 perlakuan yaitu pakan P0 (Tepung ikan 40\%+Tepung keong mas0\%), pakan P1 (Tepung ikan $30 \%+$ Tepung keong mas $10 \%$ ), pakan P2 (Tepung ikan 20\% + Tepung keong mas20\%) dan pakan P3 (Tepung ikan $10 \%+$ Tepung keong mas30\%) dengan ulangan sebanyak 5 kali. 


\section{Prosedur Kerja}

\section{Pembuatan Tepung Keong Mas}

Keong mas dicuci, direbus dan dikeluarkan dari cangkangnya. Daging keong mas dipotong kecil-kecil, dipisahkan dari usus dan organ visceral lainnya. Daging keong mas dikeringkan, ditimbang dan digiling halus untuk dijadikan tepung.

\section{Pembuatan Pakan Perlakuan}

Bahan pakan yang telah digiling dilakukan pengayakan terlebih dahulu kemudian ditimbang sesuai dengan formulasi, kemudian dilakukan pencampuran secara homogen. Ransum pakan ditambahkan dengan $\mathrm{Cr}_{2} \mathrm{O}_{3} \quad 0,5 \%$ sebagai indikator kecernaan (NRC, 1993). Pencampuran dimulai dari bahan pakan yang berukuran mikro hingga bahan pakan yang berukuran makro.

Bahan pakan yang telah tercampur secara homogen kemudian diangkat dan dicetak dengan menggunakan alat pencetak pellet. Pellet yang sudah setengah jadi kemudian dikeringkan menggunakan oven dengan suhu $70^{\circ} \mathrm{C}$ selama 24 jam. Pellet dihasilkan dalam bentuk kering ( $d r y$ pellet). Cara yang sama juga dilakukan pada proses pembuatan pakan udang untuk perlakuan $\mathrm{P}_{1}, \mathrm{P}_{2}$ dan $\mathrm{P}_{3}$.

\section{Persiapan Akuarium dan Media Pemeliharaan}

Akuarium yang akan digunakan dibutuhkan sebanyak 20 buah dengan ukuran 20x40x40 $\mathrm{cm}^{3}$. Media pemeliharaan adalah air payau dengan salinitas 15 ppt yang sebelumnya telah diaerasi selama satu hari untuk meningkatkan kandungan oksigen terlarut dalam air (DO).

\section{Pemeliharaan Udang}

Udang yang digunakan dalam penelitian ini adalah udang vannamei (Litopenaeus vannamei) ukuran konsumsi dengan berat rata-rata \pm 10 gram. Setiap akuarium diisi 5 ekor udang. Pakan dibe- rikan secara langsung ke dalam akuarium pada pukul 07.00, 12.00 dan 16.00 WIB.

\section{Pengamatan Kecernaan}

Udang diadaptasi selama 4 hari dengan diberi pakan uji. Pada hari ke 5 sampai 15 feses mulai dikumpulkan. Pengambilan feses dilakukan dengan cara penyiponan. Feses ditampung dalam botol film berlabel dan disimpan dalam lemari pendingin. Feses yang telah terkumpul dikeringkan dalam oven bersuhu $70^{\circ} \mathrm{C}$ selama 24 jam.

\section{Parameter Penelitian Parameter Uji Utama}

Nilai kecernaan serat kasar dihitung berdasarkan persamaan Takeuchi (1988):

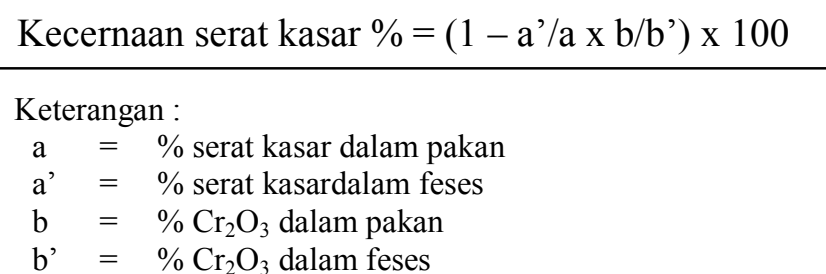

Nilai kecernaan bahan ekstrak tanpa nitrogen (BETN) dihitung berdasarkan persamaan Takeuchi (1988):

Kecernaan BETN \% $=\left(1-\mathrm{a}^{\prime} / \mathrm{a} \times \mathrm{b} / \mathrm{b}^{\prime}\right) \times 100$

$$
\begin{aligned}
\text { Keterangan : } & \\
\mathrm{a} & =\% \mathrm{BETN} \text { dalam pakan } \\
\mathrm{a}^{\prime} & =\% \mathrm{BETN} \text { dalam feses } \\
\mathrm{b} & =\% \mathrm{Cr}_{2} \mathrm{O}_{3} \text { dalam pakan } \\
\mathrm{b}^{\prime} & =\% \mathrm{Cr}_{2} \mathrm{O}_{3} \text { dalam feses }
\end{aligned}
$$

\section{Parameter Penunjang}

Parameter penunjang pada penelitian ini adalah pengukuran kualitas air meliputi suhu, salinitas, $\mathrm{pH}$ dan DO yang diukur setiap dua hari sekali pada pukul 07.00 WIB dan 16.00 WIB. Kadar amoniak diukur setiap tujuh hari sekali. Parameter kualitas air diukur selama penelitian berlangsung. 


\section{Analisis Data}

Pengolahan data dilakukan dengan perhitungan Analysis of Variance (ANOVA) untuk mengetahui pengaruh perlakuan yang diberikan apabila berbeda nyata, kemudian dilanjutkan dengan uji Jarak Berganda Duncan (Duncan's Multiple Range Test) dengan tingkat kesalahan $5 \%$ untuk mengetahui perlakuan yang terbaik (Kusriningrum, 2008). Data yang diperoleh diolah menggunakan soft-ware SPSS versi 16.

\section{Hasil}

\section{Kecernaan Serat Kasar}

Hasil perhitungan nilai kecernaan serat kasar berdasarkan kandungan serat kasar pakan dan kandungan serat kasar feses pada masing-masingperlakuan dapat dilihat pada Tabel 1.

Berdasarkan Tabel 1 dapat diketahui bahwa rata-rata nilai kecernaan tertinggi diperoleh pada perlakuan P3 dengan penggunaan $10 \%$ tepung ikan dan $30 \%$ tepung keong mas sebesar 91,26 $\pm 0,83 \%$. Penggunaan keong mas pada kadar $0 \%$ dan tepung ikan $40 \%$ (perlakuan P0) memberikan nilai kecernaan terendah sebesar $90,61 \pm 0,58 \%$. Hasil analisis ragam menunjukkan bahwa substitusi tepung keong mas terhadap tepung ikan dalam pakan udang vannamei tidak terdapat perbedaan yang nyata $(\mathrm{P}>0.05)$ terhadap nilai kecernaan serat kasar.

\section{Kecernaan Bahan Ekstrak Tanpa Nitrogen (BETN)}

Hasil perhitungan nilai kecernaan BETN berdasarkan pengamatan kandungan BETN pakan dan kandungan BETN feses pada masing-masing perlakuan tercantum pada Tabel 2.Berdasarkan Tabel 2 dapat diketahui bahwa rata-rata nilai kecernaan tertinggi diperoleh pada perlakuan P3 dengan penggunaan $10 \%$ tepung ikan dan30\% tepung keong mas sebesar 90,11 $\pm 0,44 \%$. Penggunaan keong mas pada kadar $0 \%$ dan tepung ikan $40 \%$ (perlakuan P0)memberikan nilai kecernaan terendah sebesar $89,11 \pm 0,66 \%$. Hasil analisis ragam menunjukkan bahwa substitusi tepung keong mas terhadap tepung ikan dalam pakan udang vannamei tidak terdapat perbedaan yang nyata $(\mathrm{P}>0.05)$ terhadap nilai kecernaan BETN.

\section{Pembahasan}

\section{Kecernaan Serat Kasar}

Penggunaan tepung keong mas sampai dengan kadar $75 \%$ sebagai substitusi tepung ikan pada pakan udang vannamei menunjukkan peningkatan kecernaan serat kasar, tetapi berdasarkan

Tabel 1. Rata-rata Nilai Kecernaan Serat Ka-sar pada Masing-masing Perlakuan

\begin{tabular}{ccc}
\hline \multirow{2}{*}{ Perlakuan } & Rata-rata Nilai Kecernaan (\%) \pm & Transformasi $(\sqrt{ }) \pm$ SD \\
\hline SD & $90.61 \pm 0.58$ & $9.52 \pm 0.03$ \\
P1 & $90.75 \pm 0.51$ & $9.53 \pm 0.03$ \\
P2 & $91.22 \pm 0.27$ & $9.55 \pm 0.01$ \\
P3 & $91.26 \pm 0.83$ & $9.55 \pm 0.04$ \\
\hline
\end{tabular}

Tabel 2. Rata-rata Nilai Kecernaan BETN pada Masing-masing Perlakuan.

\begin{tabular}{ccc}
\hline Perlakuan & $\begin{array}{c}\text { Rata-rata Nilai Kecernaan } \\
(\mathbf{\%}) \pm \text { SD }\end{array}$ & Transformasi $(\sqrt{ }) \pm$ SD \\
\hline P0 & $89.11 \pm 0.66$ & $9.44 \pm 0.04$ \\
P1 & $89.23 \pm 0.82$ & $9.45 \pm 0.04$ \\
P2 & $89.64 \pm 1.27$ & $9.47 \pm 0.07$ \\
P3 & $90.11 \pm 0.44$ & $9.49 \pm 0.02$ \\
\hline
\end{tabular}


hasil analisis ragam dapat dilihat pada semua pakan perlakuan tidak memberikan pengaruh yang nyata $(\mathrm{P}>0.05)$ hal ini dikarenakan kandungan serat kasar dalam pakan menurun seiring bertambahnya kadar tepung keong mas dalam pakan sehingga antar perlakuan memiliki nilai kecernaan yang sama baiknya diserap oleh tubuh udang. Berdasarkan rata-rata nilai kecernaan serat kasar pada semua pakan perlakuan memiliki kualitas bahan pakan yang sama-sama tinggi karena memiliki nilai rata-rata kecernaan diatas $70 \%$ (Abun, 2007).

Nutrisi yang terkandung dalam keong mas mulai dari protein, lemak, hingga kadar serat kasarnya hampir sama dengan kandungan nutrisi dalam tepung ikan. Hal ini sesuai dengan pendapat Subhan et al. (2010) yang menyatakan bahwa keong mas merupakan sumber protein pakan yang potensial karena kandungan proteinnya menyamai tepung ikan. Komposisi nutrien tepung keong mas berdasarkan analisis proksimat adalah bahan kering 95,14 \%, kadar abu 12,66\%, protein $56,06 \%$, lemak $6,24 \%$, serat kasar $5,03 \%$, BETN 15,16 dan energi 2887,02 $\mathrm{Kkal} / \mathrm{kg}$.

Semakin besar persentase substitusi tepung keong mas semakin tinggi persentase kecernaannya, hal ini disebabkan dari segi efisiensi pakan pada kadar substitusi hingga 75\% lebih tinggi dari pada kadar lainnya yang mengindikasikan terjadinya peningkatan penyerapan nutrisi dalam tubuh udang. Hal ini diperkuat oleh pendapat Bomboe et al. (1995), telah membandingkan asam amino esensial daging udang dengan asam amino daging keong mas mempunyai essential amino acid index (EAAI) sekitar 0,84 dan efisiensi pakan pada budidaya perikanan tergantung dari kesamaan profil asam amino pakan dengan ikan yang diberi pakan tersebut.

Secara keseluruhan kandungan serat kasar pada semua pakan perlakuan yaitu
P0 (8,92\%), P1 (8,79\%), P2(7,67\%) dan P3 (6,92\%), hal ini menunjukkan bahwa ke-4 pakan tersebut memiliki nilai serat kasar yang tidak jauh berbeda sehingga memberikan nilai kecernaan yang relatif sama. Kandungan serat kasar dalam pakan perlakuan sesuai denganstandar minimal kadar serat kasar dalam pakan buatan udang yaitu $<10 \%$ (Sumeru dan Anna, 1992).

\section{Kecernaan Bahan Ekstrak Tanpa Nitrogen (BETN)}

Penggunaan tepung keong mas sampai dengan kadar $75 \%$ sebagai substitusi tepung ikan pada pakan udang vannamei menunjukkan peningkatan kecernaan BETN, tetapi berdasarkan hasil analisis ragam dapat dilihat pada semua pakan perlakuan tidak memberikan pengaruh yang nyata $(\mathrm{P}>0.05)$ hal ini menunjukkan bahwa antar perlakuan memiliki nilai kecernaan yang sama sehingga sama baiknya diserap oleh tubuh udang. Nilai kecernaan BETN tertinggi terdapat pada perlakuan P3 sebesar 90,11 $\pm 0,44 \%$ kemudian diikuti oleh perlakuan P2

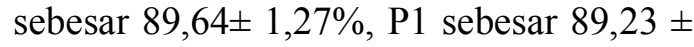
$0,82 \%$ dan perlakuan P0 menunjukkan hasil terendah dengan nilai $89,11 \pm 0,66 \%$.

Berdasarkan rata-rata nilai kecernaan BETN pada semua pakan perlakuan memiliki kualitas bahan pakan yang samasama tinggi karena memiliki nilai rata-rata kecernaan diatas 70\% (Abun, 2007). Kandungan BETN pada tepung ikan $(12,84 \%)$ tidak jauh berbeda dengan kandungan BETN dalam tepung keong mas (15,16\%), hal ini menunjukkan bahwa udang dapat memaksimalkan penggunaan nutrisi untuk dipecah menjadi molekul yang lebih sederhana sehingga dapat dengan mudah diserap dalam tubuh udang melalui saluran pencernaan, oleh karena itu nilai kecernaannya mengalami kenaikan seiring dengan bertambahnya kadar keong mas dalam pakan. 
Tabel 3. Pengukuran Kualitas Air

\begin{tabular}{lcc}
\hline \multicolumn{1}{c}{ Parameter } & Optimal & Pemeliharaan \\
\hline Suhu $\left({ }^{\circ} \mathrm{C}\right)$ & $24-30$ & $26-29$ \\
Salinitas $(\%$ oo & $15-45$ & $15-16$ \\
DO $(\mathrm{ppm})$ & $3-12$ & 6 \\
$\mathrm{pH}$ & $8,1-9,0$ & 8,0 \\
Amoniak & 0,5 & $0,25-0,5$ \\
\hline
\end{tabular}

Pemberian pakan perlakuan dengan komposisi $75 \%$ tepung keong mas yang dipelihara selama 14 hari menghasilkan nilai kecernaan BETN yang tidak berbeda nyata dengan nilai kecernaan BETN pada penggunaan pakan $100 \%$ tepung ikan. Beberapa hasil penelitian menunjukkan bahwa penggantian sebagian tepung ikan sebagai sumber protein dalam pakan oleh bahan-bahan lain yang kandungan nutrisinya relatif sama dapat dilakukan. Oleh karena itu penggunaan tepung keong mas dalam ransum pakan harus diformulasikan dengan tepat untuk menekan biaya pengadaan pakan. Sesuai dengan Bomboe et al. (1995) yang menjelaskan bahwa, keong mas (Pomacea canaliculata Lamarck) meru-pakan salah satu sumber protein yang baik bagi ikan, karena dagingnya mempunyai kadar protein $54 \%$ dan mengandung lemak 4,6\%. Kandungan protein yang cukup tinggi ini maka keong mas dapat dicampurkan pada formulasi pakan ikan dan dapat meminimalkan biaya pakan.

Kebutuhan BETN dalam ransumpakan harus diformulasi pada tingkatannilai kebutuhan protein tertentu sehingga seluruhnilai manfaat zat makanan dalam ransum menjadioptimal.Kandungan BETN dalam pakan udang juga perlu diperhatikan karena BETN merupakan fraksi dari karbohidrat yang diperlukan sebagai sumber energi.Hal tersebut diperkuat oleh Silva et al. (2000) bahwa kemampuan ikan (udang) dalam memanfaatkan komponen pakan selain protein memberikan andil yang cukup besar dalam kecernaan energi (protein sparing effect) dengan menggunakan lemak dan kabohidrat sebagai sumber energi.

\section{Kualitas Air Pemeliharan}

Kualitas air merupakan salah satu faktor yang mempengaruhi tingkat kelangsungan hidup dan pertumbuhan udang selama pemeliharaan. Parameter paling penting dalam kualitas air adalah suhu, oksigen terlarut (DO), $\mathrm{pH}$, dan sali-nitas, tetapi parameter lain juga berpenga-ruh pada udang. Pengukuran kualitas air berdasarkan Lucas dan Southgate (2003) dapat dilihat pada Tabel 3.

Berdasarkan Tabel 3 dapat diketahui bahwa kualitas air dalam media pemeliharaan secara keseluruhan telah memenuhi persyaratan bagi kehidupan udang sehingga memberikan nilai kecernaan serat kasar dan bahan ekstrak tanpa nitrogen (BETN) yang tidak berbeda nyata.

\section{Kesimpulan Dan Saran}

Berdasarkan hasil penelitian dapat diperoleh kesimpulan sebagai berikut :

1. Penggunaan tepung keong mas sampai dengan kadar $75 \%$ sebagai substitusi tepung ikan pada pakan udang vannamei (Litopenaeus vannamei) menunjukkan tidak terdapat pengaruh yang nyata terhadap nilai kecernaan serat kasar.

2. Penggunaan tepung keong mas sampai dengan kadar $75 \%$ sebagai substitusi tepung ikan pada pakan udang vannamei (Litopenaeus vannamei) menunjukkan tidak terdapat pengaruh yang nyata terhadap nilai kecernaan bahan ekstrak tanpa nitrogen (BETN). 
Pemafaatan tepung keong mas sampai dengan kadar $75 \%$ sebagai substitusi tepung ikan dapat digunakan dalam pembuatan pakan udang vannamei (Litopenaeus vannamei) karena memiliki kandungan serat kasar dan bahan ekstrak tanpa nitrogen (BETN) yang dicerna sangat baik oleh udang, sehingga dapat diterapkan oleh para pembudidaya udang vannamei untuk meminimalisir biaya pengadaan pakan.

\section{Daftar Pustaka}

Abun. 2007. Pengukuran Nilai Kecernaan Ransum yang Mengandung Limbah Udang Windu Produk Fermentasi pada Ayam Broiler. Makalah Ilmiah. Fakultas Peternakan Universitas Padjajaran. Bandung.hal. 34.

Bakara O, Santoso L dan Heptarina D. 2012. Enzim Mananase dan Fermentasi Jamur untuk Meningkatkan Kandungan Nutrisi Bungkil Inti Sawit pada Pakan Ikan Nila BEST (Oreochromis niloticus). Jurnal Ilmu Perikanan dan Sumberdaya Perairan. (3) : 69-72.

Bomboe T., S. Fukumoto and E.M. Rodriquez. 1995. Use of the Golden Apple Snail, Cassava and Maize as Feeds for Tiger Shrimp, Penaeus monodon in Pond. Aquaculture. pp. 91-92.

Budiman, A., T. Dhalika dan B. Ayuningsih. 2006. Uji kecernaan serat kasardan bahan ekstrak tanpa nitrogen(BETN)dalan ransum lengkap berbasis hijauan daun pucuk tebu (Saccharum officinarum). JurnalIlmu Ternak,6(2) : 132-135.

Kusriningrum, R. S. 2008. Perancangan Percobaan. Universitas Airlangga. Surabaya. hal. 43-63.

Lovell, T. 1998. Nutrition And feeding of Fish. Second Edition. Kluwer Academic Publishers. Norwell. Massachusetts. USA.
Lucas, J. S. and P. C. Southgate. 2003. Aquaculture Farming Aquatic Animals and Plants. Fishing News Books. Blackwell Publishing Company, Oxford. pp. 404-410.

National Research Council. 1993. Nutrient Requirement of Fish.National Academy Press. Washington, D.C. pp. 48 .

Silva, D. 1989.Digestibility evaluations of natural and artificial feeds, p. 3645.In S.S. De Silva (ed.) Fish Nutrition Research in Asia. Proceedings of the Third Asian Fish Nutrition network Meeting. Asian Fish. Soc. Spec. Pubhl.4. Asian Fisheris Society, Manila, Philippines. $166 \mathrm{p}$

Subhan, A., T. Yuwanta, J.HP.Sidadolog dan E.S. Rohaeni. 2010. Pengaruh kombinasi sagu kukus (Metroxylon pp) dan tepung keong mas (Pomacea Spp) sebagai pengganti jagung kuning terhadap penampilan itik jantan alabio, mojosari dan MA. JITV Vol. 15 No.3 : 165-173.

Sumeru, S. U. dan Suzy, A. 1992. Pakan Udang Windu. Kanisius. Jakarta. hal. 14-18, 38.

Takeuchi, R. P. 1898. Amino Acids and Protein. In Fish Nutrition. J. E. Halver (eds). Academic Press, Inc. New York. pp. 111.

Tarigan, S. J. B., 2008. Pemanfaatan Tepung Keong Mas Sebagai Substitusi Tepung Ikan dalam Ransum Terhadap Performans Kelinci Jantan Lepas Sapih. Skripsi. Departemen Peternakan Fakultas Pertanian. Universitas Sumatera Utara. Medan.

Tillman, A. D., H. Hartadi, S. Reksohadiprodjo, S. Prawirokusumo, S. Lebdosoekoyo. 1983. Ilmu Makanan Ternak Dasar. Gajah Mada University Press. Yogyakarta.hal. 15252. 